\title{
Identification of suitable Landfill Site for Solid Waste in a Small Town of Uttar Pradesh
}

\author{
Lubna Siddiqui \\ Assistant Professor, Department of Geography, Jamia Millia Islamia, New Delhi, India
}

\begin{abstract}
Municipal solid waste generation rate is over-riding the population growth rate not only in mega-cities but also in small towns in India. Management of solid waste has emerged as challenge to the civic authorities. The present study aims at examining the different aspects of solid waste and suggests remedial measures for safe disposal of waste. The study is based on field survey. It is concluded that though the waste generation rate in the study area is only $0.27 \mathrm{~kg} / \mathrm{head} /$ day yet because of financial crunch and public apathy the waste is littered on the roads and streets and unhygienically dumped in the river bed and ditches. Based on the A financial accounting for the waste management has been carried out. Based on the guidelines of CPCB, a land fill site has been identified. Finally a financial accounting for the waste management has been carried out. At present per capita expenditure on waste management is about Rs. 417/. If the proposed plan is implemented the per capita expenditure on waste management will be Rs. 635/ but the efficiency will increase manifold.
\end{abstract}

Keywords: Solid waste, Generation rate, Land fill site, Financial accounting

\section{Introduction}

Municipal Solid Waste (MSW) is a term usually applied to a heterogeneous collection of wastes produced in urban areas, the nature of which varies from region to region. Urban society rejects and generates solid material regularly due to rapid increase in production and consumption. The quantity of generated solid waste depends on population and people s living standards (Grossmann et.al., 1974, Wertz, 1976) income level (Medina, 1997) economic growth, consumption pattern and institutional framework. The estimated solid waste generation in India ranges from $100 \mathrm{~g}$ per capita per day in small towns, 300-400 g per capita in medium cities and about 500 g per capita per day in large cities (Singhal and Pandey, 2001, Siddiqui, 2012). Municipal solid waste generation rate is over-riding the population growth rate not only in mega-cities but also in small towns in India. Municipal bodies spend approximately Rs. 500 to Rs. 1500 per ton for solid waste management and about 60 - 70 per cent of this amount is spent on collection, 20 - 30 per cent on transportation and less than 5 per cent on final disposal (Disha et al., 2001). However, as per the estimates of Kumar and Gaikwad (2004) municipal agencies in India spend about 5-25\% of their budget on waste management which is Rs. 75-250 per capita per year.

The collection services are deficient for up to 20 percent of the urban population in developing countries (Al-Khatib et al. 2010). The most common disposal method is open and uncontrolled dumping at dumpsite, streets, drains, rivers as well as burning in the backyard, roadside and dumpsites (Environmental Foundation, 2007). Inadequate waste management and disposal practices combined with the tropical climatic influence results in increasing environmental problems in Asian regions (Visvanathan et al, 2004).

It is only recently that the problems of waste management in developing countries are started to be seriously addressed and waste generation reduction is being considered an educational and awareness task which has to be promoted at societal level (Agamuthu and Hansen, 2007). MSW management encompasses the functions of collection, transfer and transportation, processing \& recycling, and disposal of MSW. Safe and cost-effective management of MSW is a significant environmental challenge for modern society.

\section{The Study Area}

With an area of only 2.34 sq. km, population of 29,236 and a density of 12,494 persons per square $\mathrm{km}$, Jalalpur is the smallest Nagar Palika but second largest business town of Ambedkarnagar district. It has 25 wards (Figure 1). The town is situated at $26^{\circ} 25^{\mathrm{ee}} 00 \mathrm{~N}$ latitude and $80^{\circ} 22^{\mathrm{ee}} 00 \mathrm{E}$ longitude on the right bank of the sacred river Tons (Tamsa). 


\section{International Journal of Science and Research (IJSR) \\ ISSN (Online): 2319-7064}

Index Copernicus Value (2013): 6.14 | Impact Factor (2014): 5.611

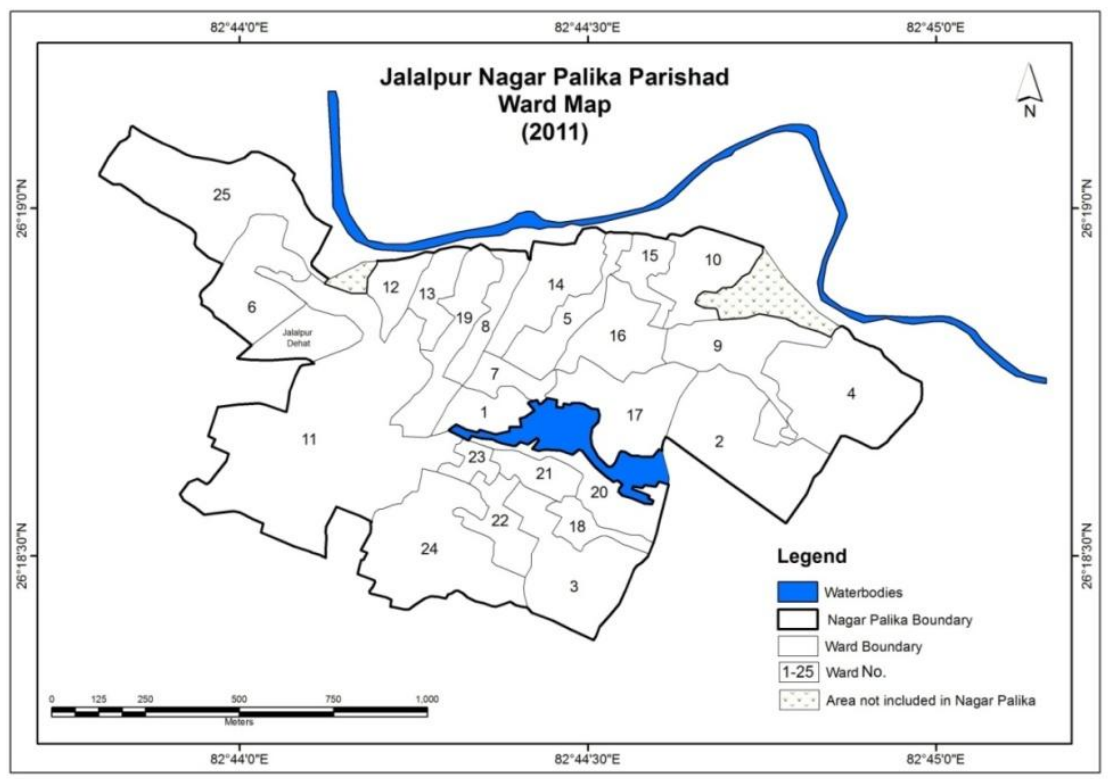

Figure 1: Jalalpur: Wards

The town is Muslim dominated and has a typical character. Handlooms and power looms are the only source of income for majority of the population. Jalalpur is famous for handloom products like lungi and Urdu shairy. The town has grown from a village to Notified area to Town area and currently to Nagar Palika but because of political reasons the limits remain unchanged for about more than 50 years. It has been reflected in poor revenue generation which ultimately affects the development plans.

\section{Objectives:}

The objectives of the study are:

To estimate the waste generation rate for Jalalpur town

To examine the waste collection methods

To identify suitable landfill site

To examine the financial condition of the civic body visavis waste management

\section{Database and Methodology}

In the absence of house-to-house data collection, the quantity of waste generation is assessed by indirect ways. Population, income, literacy, work force etc are the important parameters, used for the estimation of waste generation. However, most of estimations are based on per capita income.

Spatial data were obtained from Google Image, Survey of India, Topographic Sheet $63 \mathrm{~J} / 13$ on 1:50,000, and Nazri Naqsha. The non -spatial data is obtained from Census of India, Uttar Pradesh, 2001, containing ward wise information.

Data regarding income, solid waste generation, collection, transportation and disposal has been taken with the help of structured questionnaire. For this purpose, ward wise household sample survey has been conducted. One hundred fifty households were randomly selected.

In order to quantify waste collected at each bin, both visual (volume estimation) and weighing experiments were carried out for 10 bins in Jalalpur. An exploratory field investigation was carried out to find the type and characteristics of waste during April and September, 2011. The bins were monitored for seven days. For the identification of new disposal site constraints mapping was applied to minimize the search area. The constraints mapping was under taken for the selected locational factors as proposed by the CPCB.

\section{Results and Discussion}

\section{Waste Generation}

Jalalpur with population of 29,236 generates about 7.836 tonnes of waste daily. The average rate is about 0.270 $\mathrm{kg} /$ head/day ranging between $0.207 \mathrm{~kg} /$ head/day in Wajidpur ward and $0.401 \mathrm{~kg} / \mathrm{head} /$ day in Neem Tal Paschimi ward (Table-1). Though the average generation rate is in control yet about 25 per cent population has reported generation rate of more than 300 grams per head per day. It signifies that sooner or later the significant population will fall in this category. The spatial pattern is specific in nature. All the wards falling in the western part of the town recorded very low generation rate $(<0.250 \mathrm{~kg} / \mathrm{head} /$ day $)$. With few exceptions, all such wards have low concentration of population. Such wards account for about 17.47 per cent population and 14.17 per cent waste. Whereas the wards close to the river are the biggest generators (Table 1). 


\section{International Journal of Science and Research (IJSR) \\ ISSN (Online): 2319-7064}

Index Copernicus Value (2013): 6.14 | Impact Factor (2014): 5.611

Table 1: Jalalpur: Waste Generation - 2011

\begin{tabular}{|c|c|c|}
\hline Ward No. & Ward Name & $\mathrm{kg} /$ person/day \\
\hline 1. & Chachu Purvi & 0.266 \\
\hline 2. & Usman Pur Dakshni & 0.269 \\
\hline 3. & Jafrabad Dakshni-Purvi & 0.299 \\
\hline 4. & Usman Pur Purvi & 0.263 \\
\hline 5. & Neem Tal Purvi & 0.368 \\
\hline 6. & Wajidpur Purvi & 0.222 \\
\hline 7. & Chajja Paschmi & 0.364 \\
\hline 8. & Paschim Taraf Purvi & 0.256 \\
\hline 9. & Usman Pur Madhya & 0.253 \\
\hline 10. & Usman Pur Paschmi & 0.302 \\
\hline 11. & Ghasiyari tola & 0.239 \\
\hline 12. & Paschim Taraf Paschim & 0.271 \\
\hline 13. & Paschim Taraf Madhya & 0.264 \\
\hline 14. & Neem Tal Paschimi & 0.401 \\
\hline 15. & Kazi Pura & 0.304 \\
\hline 16. & Dala Tola & 0.308 \\
\hline 17. & Ganja & 0.245 \\
\hline 18. & Jafrabad Purvi & 0.249 \\
\hline 19. & Paschim Taraf Uttari & 0.256 \\
\hline 20. & Jafrabad Uttari & 0.277 \\
\hline 21. & Jafrabad Madhya & 0.256 \\
\hline 22. & Jafrabad Dakshni- Paschimi & 0.294 \\
\hline 23. & Jafrabad Paschimi & 0.300 \\
\hline 24. & Jafrabad Dakshni & 0.263 \\
\hline 25. & Wajidpur & 0.201 \\
\hline Average & & 0.270 \\
\hline
\end{tabular}

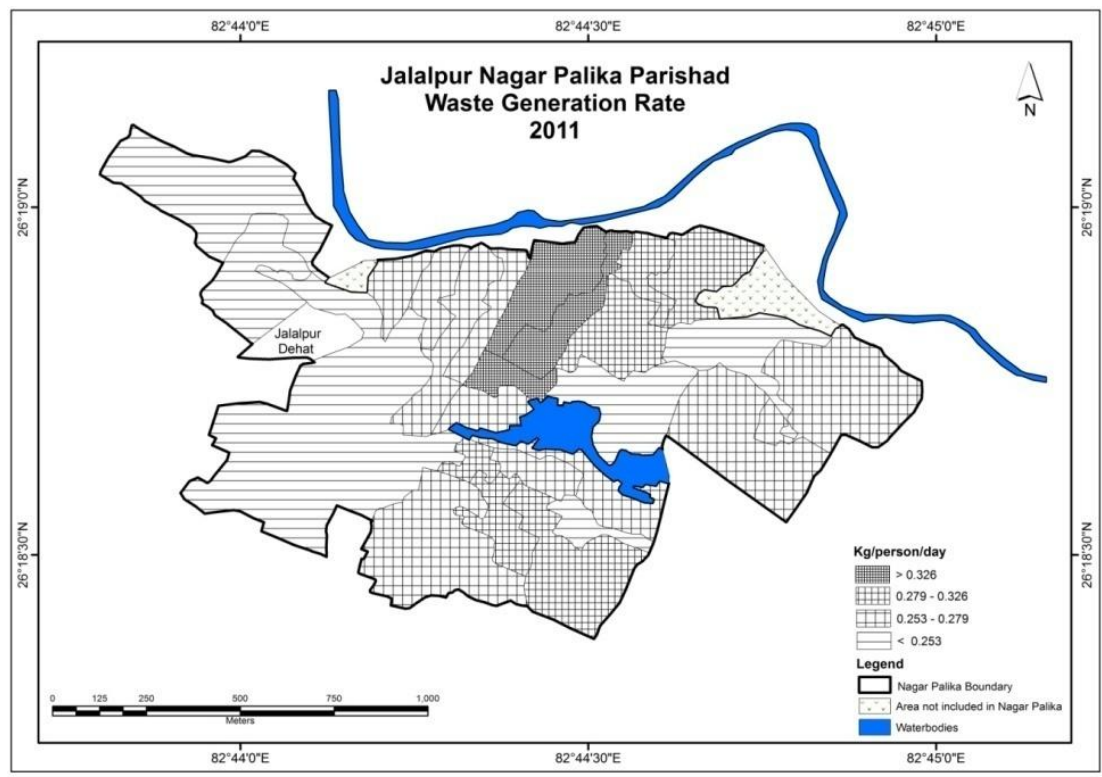

Figure 2: Jalalpur: Waste Generation

Table 2: Jalalpur: Waste Generation (Category wise)

\begin{tabular}{|c|c|c|c|}
\hline $\begin{array}{c}\text { Waste } \\
\text { Category }\end{array}$ & Population & $\begin{array}{c}\text { Waste in } \\
\mathrm{Kg}\end{array}$ & $\begin{array}{c}\text { Percent of } \\
\text { Total Waste }\end{array}$ \\
\hline$<0.250$ & $4920(17.47)$ & 1110 & 14.17 \\
\hline $0.25-0.300$ & $16436(58.38)$ & 4431 & 55.65 \\
\hline $0.300-0.350$ & $3765(13.37)$ & 1145 & 14.61 \\
\hline $0.350-0.400$ & $1831(6.50)$ & 670 & 8.55 \\
\hline$>0.400$ & $1198(4,25)$ & 480 & 6.13 \\
\hline Total & $\mathbf{2 8 1 5 0}$ & $\mathbf{7 8 3 6 / 7 . 8 3}$ & $\mathbf{1 0 0}$ \\
\hline
\end{tabular}

Figures in parenthesis show percent.

Low rate of waste generation is recorded in the central part and eastern part of the town. These wards make contiguous region with occasional interruption by the wards with high and very high generation rate. These wards are densely populated ( $>11000$ person $/ \mathrm{km}$ ) and account for about 58.38 per cent population and 55.65 per cent waste. It is found that there are only two wards with generation rate of more than $0.350 \mathrm{~kg} /$ head/day. These wards account for about 10.75 per cent population and 14.68 per cent waste. Both these wards extend from central part to the bank of Tons river. 


\section{International Journal of Science and Research (IJSR) ISSN (Online): 2319-7064 \\ Index Copernicus Value (2013): 6.14 | Impact Factor (2014): 5.611}

Table 3: Jalalpur: Waste Generation (Income wise) - 2011

\begin{tabular}{|c|c|c|c|}
\hline Income in Rs & Population & $\begin{array}{c}\text { Waste Quantity } \\
\text { in ton }\end{array}$ & $\begin{array}{c}\text { Waste } \\
\text { Kg/head/day }\end{array}$ \\
\hline$<3000$ & $18498(65.71)$ & $4.69(59.85 \%)$ & 0.28 \\
\hline $3000-5000$ & $6623(23.52)$ & $1.996(25.47 \%)$ & 0.31 \\
\hline$>5000$ & $3029(10.76)$ & $1.150(14.58 \%)$ & 0.35 \\
\hline Total/Average & $\mathbf{2 8 1 5 0}$ & $\mathbf{7 . 8 3 6}$ & $\mathbf{0 . 3 1 3}$ \\
\hline
\end{tabular}

Due to poor resources of income generation, a sizeable population lives below poverty line. About 65.71 per cent population earn less than Rs.3000/ a month and about 23.52 per cent have a monthly income between Rs. $3000-5000$. These two income group account for about 89.23 per cent population and 85 per cent waste of the town. Only 10.76 per cent population earn more than Rs. 5000/ month. This category includes the richest of the town (Table 3).
The difference between organic and inorganic waste is insignificant. Of the total waste, about 49.1 per cent is organic and the remaining 50.9 per cent is organic in nature, but on the dumping sites only inorganic materials are found as left over items (Table 2). The settlement along the Urdu Bazaar Road is the core of the town and generates maximum quantity of both organic and inorganic waste. The western part consisting of Wajidpur ward is newly developed and is sparsely populated; even the inorganic waste is high because of local taxi stand and market. It is found that majority of the wards close to the river are the highest generator of inorganic waste and it is dumped in the river bed. All the inhabitants of this part have encroached upon the river (Figure 2).

Table 4: Jalalpur: Waste Characteristics

\begin{tabular}{|c|c|c|c|c|c|c|}
\hline \multirow[b]{2}{*}{ S. No. } & \multirow[b]{2}{*}{ Ward Name } & \multirow{2}{*}{$\frac{\text { Waste }}{\mathrm{kg} / \text { person/day }}$} & \multicolumn{2}{|c|}{ Organic Waste } & \multicolumn{2}{|c|}{ Inorganic Waste } \\
\hline & & & Percent & kg/head/day & Percent & kg/head/day \\
\hline 1. & Chajja Purvi & 0.266 & 65.12 & 0.173 & 34.88 & 0.092 \\
\hline 2. & Usman Pur Dakshini & 0.269 & 48.89 & 0.131 & 51.11 & 0.137 \\
\hline 3. & Jafrabad Dakshini-Purvi & 0.299 & 51.00 & 0.152 & 49 & 0.146 \\
\hline 4. & Usman Pur Purvi & 0.263 & 52.78 & 0.139 & 47.22 & 0.124 \\
\hline 5. & Neem Tal Purvi & 0.368 & 54.78 & 0.202 & 45.22 & 0.166 \\
\hline 6. & Wajidpur Purvi & 0.222 & 45.98 & 0.102 & 54.02 & 0.120 \\
\hline 7. & Chajja Paschimi & 0.364 & 61.67 & 0.224 & 38.33 & 0.139 \\
\hline 8. & Paschim Taraf Purvi & 0.256 & 35.78 & 0.091 & 64.22 & 0.164 \\
\hline 9. & Usman Pur Madhya & 0.253 & 50.34 & 0.127 & 49.66 & 0.126 \\
\hline 10. & Usman Pur Paschmi & 0.302 & 55.65 & 0.168 & 44.35 & 0.133 \\
\hline 11. & Ghasiyari Tola & 0.239 & 64.45 & 0.154 & 35.55 & 0.085 \\
\hline 12. & Paschim Taraf Paschim & 0.271 & 37.08 & 0.100 & 62.92 & 0.170 \\
\hline 13. & Paschim Taraf Madhya & 0.264 & 36.76 & 0.097 & 63.24 & 0.167 \\
\hline 14. & Neem Tal Paschimi & 0.401 & 49.45 & 0.198 & 50.55 & 0.203 \\
\hline 15. & Kazi Pura & 0.304 & 57.54 & 0.175 & 42.46 & 0.129 \\
\hline 16. & Dalal Tola & 0.308 & 56.34 & 0.173 & 43.66 & 0.134 \\
\hline 17. & Ganja & 0.245 & 50.45 & 0.123 & 49.55 & 0.121 \\
\hline 18. & Jafrabad Purvi & 0.249 & 54.78 & 0.136 & 45.22 & 0.112 \\
\hline 19. & Paschim Taraf Uttari & 0.256 & 38.97 & 0.099 & 61.03 & 0.156 \\
\hline 20. & Jafrabad Uttari & 0.277 & 49.75 & 0.138 & 50.25 & 0.139 \\
\hline 21. & Jafrabad Madhya & 0.256 & 52.54 & 0.134 & 47.46 & 0.121 \\
\hline 22. & Jafrabad Dakshni- Paschimi & 0.294 & 55.92 & 0.164 & 44.08 & 0.129 \\
\hline 23. & Jafrabad Paschimi & 0.300 & 48.45 & 0.145 & 51.55 & 0.154 \\
\hline 24. & Jafrabad Dakshni & 0.263 & 45.67 & 0.120 & 54.33 & 0.143 \\
\hline 25. & Wajidpur & 0.201 & 44.25 & 0.089 & 55.75 & 0.112 \\
\hline & Total/Average & 0.270 & 49.10 & 0.142 & 50.89 & 0.137 \\
\hline
\end{tabular}




\section{International Journal of Science and Research (IJSR) \\ ISSN (Online): 2319-7064}

Index Copernicus Value (2013): 6.14 | Impact Factor (2014): 5.611

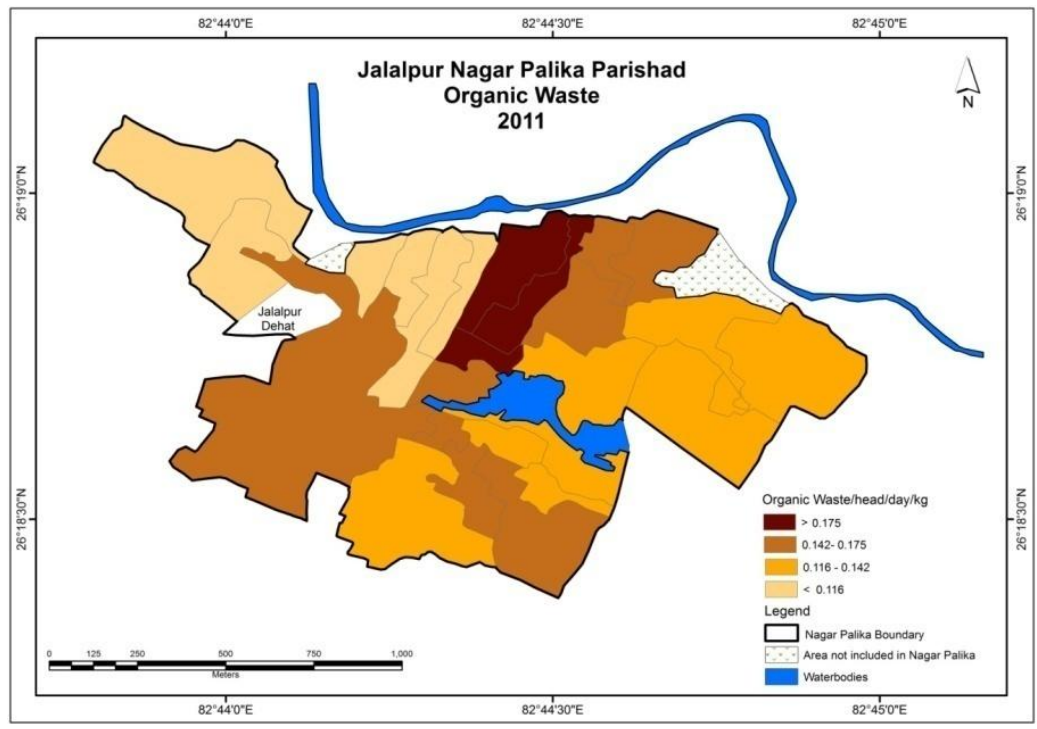

Figure 3: Jalalpur: Organic Waste

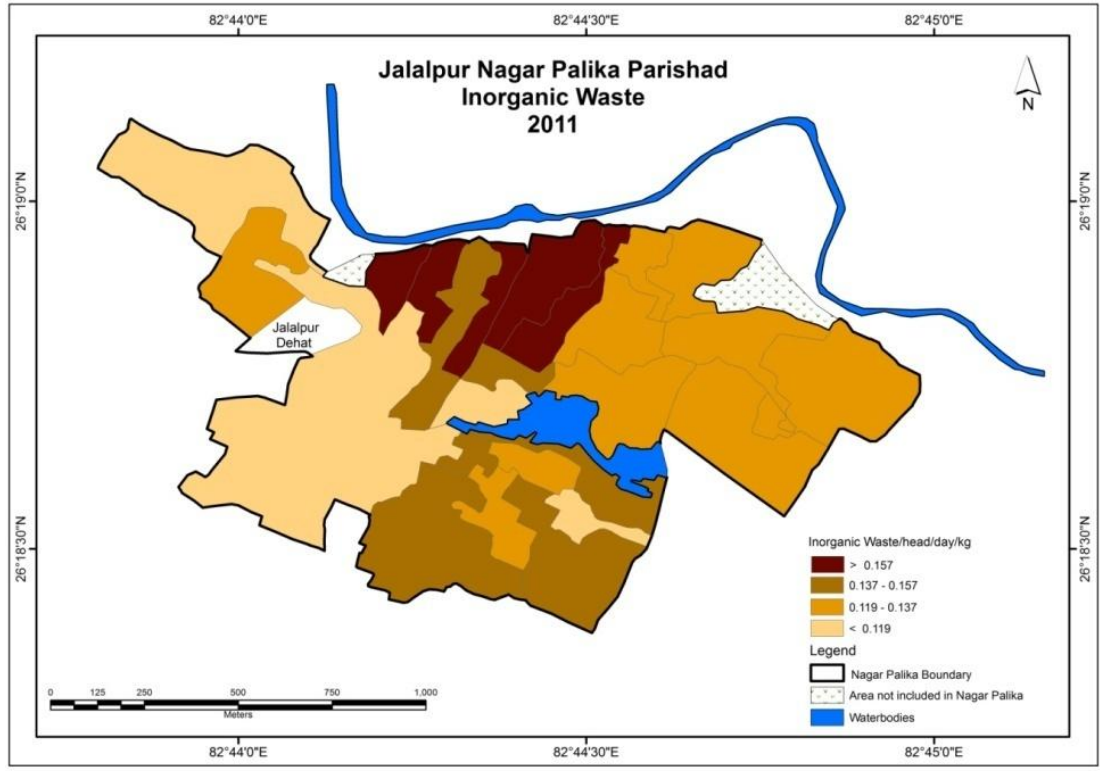

Figure 4: Jalalpur: Inorganic Waste

\section{Waste Collection}

Uncollected waste has become a common sight in most of the wards. The situation in the old parts of the town is grim as less than 50 per cent of the waste is collected and disposed. Various reasons have been forwarded for this situation, among them: inadequate capacity of Nagar Palika, finances and poor planning. In spite of the rapid increase in population, evidences show that expenditure by the Nagar Palika on infrastructure and services has been reducing progressively. As would be expected, the low-income areas of the towns are most affected by the poor management of solid waste. These areas are mainly dense settlements and occupied by working population. Though the sweeperpopulation ratio appears good there are variations within the town. The average ratio is 369.20 , better than the recommended one. It ranges between 201.25 in Paschim Taraf Uttari and 607.80 in Wajidpur Purvi ward. These variations are attributed to the political influence and randomness in the deputation of sanitary staff. The analysis reveals that though best ratio is found in Jalalpur yet this is the only town where the collection and disposal rate is worst. 


\section{International Journal of Science and Research (IJSR) \\ ISSN (Online): 2319-7064}

Index Copernicus Value (2013): 6.14 | Impact Factor (2014): 5.611

\begin{tabular}{|c|c|c|c|c|}
\hline \multicolumn{5}{|c|}{ Table-5 } \\
\hline S. No. & Ward & Bin - Population Ratio & Sweeper - Road Length Ratio (in meters) & Sweeper - Population Ratio \\
\hline 1. & Chachu Purvi & 1543 & 295.31 & 482.18 \\
\hline 2. & Usman Pur Dakshini & 1819 & 356.87 & 568.43 \\
\hline 3. & Jafrabad Dakshini-Purvi & 1205 & 1014.06 & 376.56 \\
\hline 4. & Usman Pur Purvi & 1063 & 492.18 & 332.18 \\
\hline 5. & Neem Tal Purvi & 761 & 660.94 & 237.81 \\
\hline 6. & Wajidpur Purvi & 1945 & 1000.62 & 607.80 \\
\hline 7. & Chajja Paschimi & 1070 & 285.00 & 334.37 \\
\hline 8. & Paschim Taraf Purvi & 1755 & 438.12 & 548.44 \\
\hline 9. & Usman Pur Madhya & 1127 & 873.43 & 352.18 \\
\hline 10. & Usman Pur Paschimi & 1724 & 606.25 & 538.75 \\
\hline 11. & Ghasiari Tola & 1295 & 1862.50 & 404.69 \\
\hline 12. & Paschim Taraf Paschimi & 1145 & 265.00 & 367.03 \\
\hline 13. & Paschim Taraf Madhya & 1212 & 370.62 & 378.75 \\
\hline 14. & Neem Tal Paschimi & 1198 & 875.31 & 374.37 \\
\hline 15. & Kazi Pura & 986 & 432.18 & 308.12 \\
\hline 16. & Dala Tola & 1055 & 809.68 & 325.69 \\
\hline 17. & Ganja & 735 & 411.87 & 229.68 \\
\hline 18. & Jafrabad Purvi & 1386 & 732.18 & 433.12 \\
\hline 19. & Paschim Taraf Uttari & 644 & 717.18 & 201.25 \\
\hline 20. & Jafrabad Uttari & 1229 & 540.00 & 384.06 \\
\hline 21. & Jafrabad Madhya & 975 & 390.62 & 304.68 \\
\hline 22. & Jafrabad Dakshni- Paschimi & 766 & 533.12 & 239.37 \\
\hline 23. & Jafrabad Paschimi & 887 & 190.31 & 277.18 \\
\hline 24. & Jafrabad Dakshni & 1066 & 585.00 & 333.12 \\
\hline 25. & Wajidpur & 1045 & 1067.81 & 326.55 \\
\hline & Total/Average & 1181.44 & 617.85 & 369.20 \\
\hline
\end{tabular}

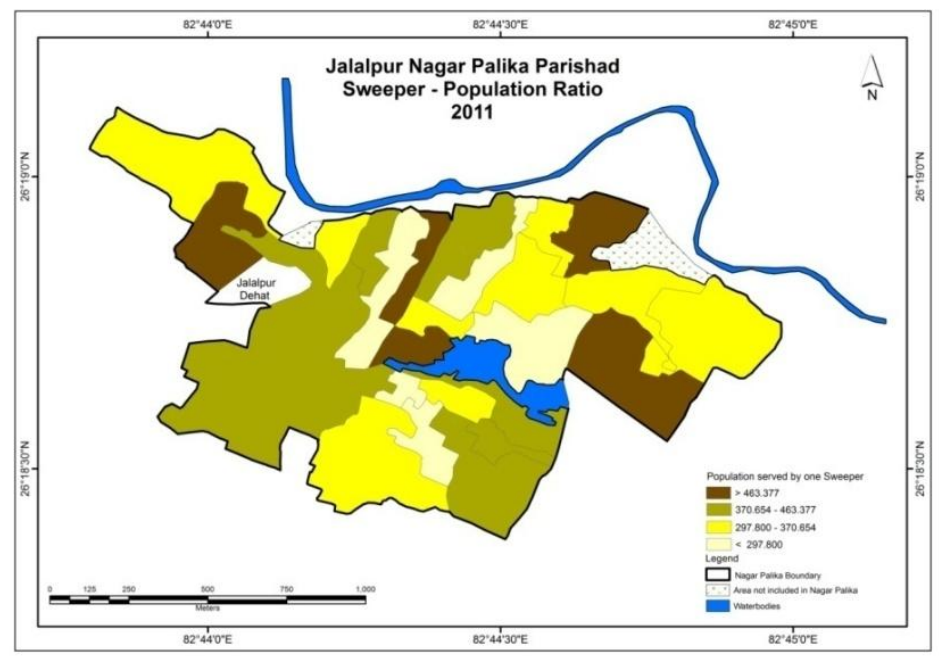

Figure 5: Jalalpur: Sweeper-population ratio

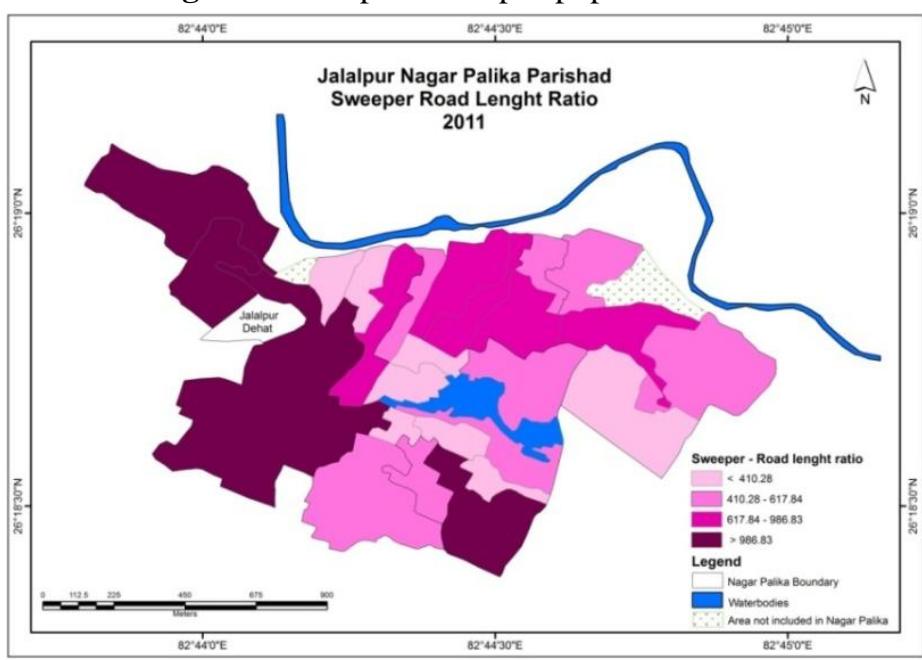

Figure 6: Jalalpur: Sweeper-road length ratio

Volume 5 Issue 2, February 2016 www.ijsr.net 


\section{International Journal of Science and Research (IJSR) \\ ISSN (Online): 2319-7064}

Index Copernicus Value (2013): 6.14 | Impact Factor (2014): 5.611

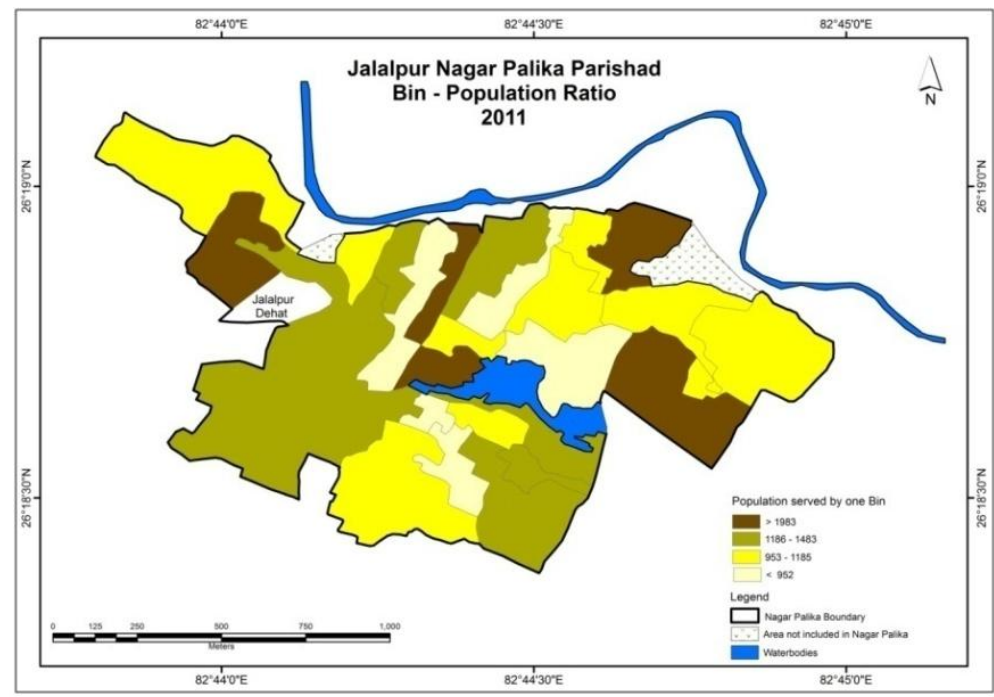

Figure 7: Jalalpur: Bin-population ratio

There is no bench mark or yardstick prescribed by the municipal authorities for street sweeping. Generally, the assigned road length for sweeper ranges between 250 to 1000 meters. However, in some place sweeper may be allotted an area of about 3000 sq meters or more. The Central Public and Environmental Engineering Organisation (CPHEEO) estimate that a sweeper can sweep 300 to 350 running meters in high density areas, 500 to 600 meters in medium density areas and 650 to 700 running meters in low density areas. In most of the major cities of Uttar Pradesh the average is around 200 sq. meters per sweeper.

In spite of the best ratio the roads are littered and garbage along the road side is a common site. The people are least concerned about hygiene. Average ratio is 1:617 which is in conformity with the recommendation of both $\mathrm{CPCB}$ and CPHEEO. The best ratio of 190.31 is recorded in Jafrabad Paschimi and the worst of 1862 in Ghasiari Tola followed by 1067.81 in Wajidpur, Jafrabad Dakshini Purvi and Wajidpur Purvi. In the remaining wards the ratio is better than recommended ratio. Again the deputation of the safai karamchari is political rather need based (Table 5 and Figure 5).

The town with 25 wards and about 29,000 populations has only one dust bin per ward. The fact is enough to unhide the story of waste management. The average ratio is 1:1181.44 but not too low when compared with Tanda. The best ratio of 1:644 is recorded in Paschim Taraf Uttari followed by Ganja and Neem Tal Purvi whereas the worst ratio of 1945 is in Wajidpur Purvi followed by Usman Pur Dakshini (Table 5 and Figure 6). In nut shell the ratio is inverse to density of the wards. Higher the population density, poor is the ratio.

In order to improve upon the existing bin-population ratio, buffer of 25 meters for every dustbin has been drawn in each town and noted the population served. The population in 25 meter radius 400 persons. On an average each urban ward has a population of 3500 . Considering that 10 dustbins are put in each ward and each dust bin has to serve a population of 250, it is estimated that the number of dust bins in each ward be at least 14 . This way a total of 168 dustbins are needed but currently there are only 125 dustbins. If we apply the same principle for all the wards of the Nagar Palika the results depict something alarming. For, if 125 dust bins are equally distributed over all the wards, the average per ward is only 5 and the total requirement will of 350 dust bins. In case of Jalalpur there are only 25 dust bins (one bin for each ward) for a population of 29000. It has been estimated that 73 bins are required. It means 48 additional dust bins are required.

\section{Land use:}

Jalalpur Nagar Palika has a typical character. The town particularly the core which is a mix of houses, power looms and market is densely populated and congested. Movement of vehicles during day time is rather impossible. About 77 per cent area is under settlement followed by 17.92 per cent under road (lanes and bye lanes). The remaining area is under various classes of low magnitude (Table 6 and Figure 8). 


\section{International Journal of Science and Research (IJSR) \\ ISSN (Online): 2319-7064}

Index Copernicus Value (2013): 6.14 | Impact Factor (2014): 5.611

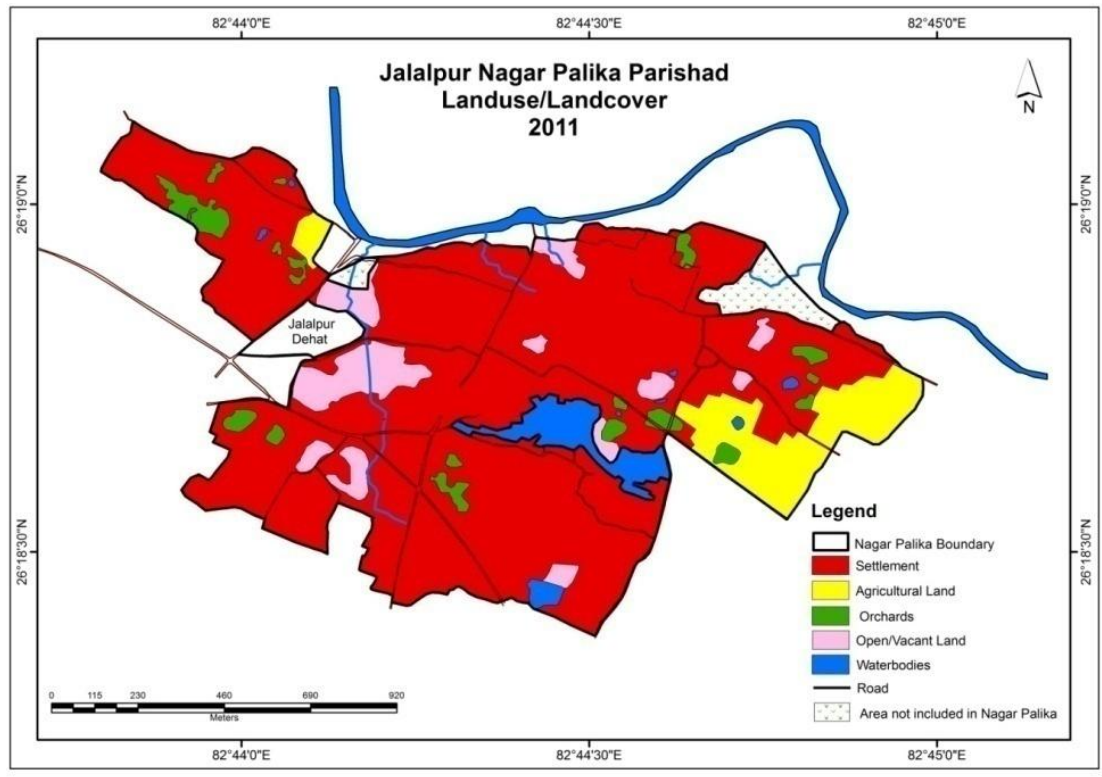

Figure 8: Jalalpur: Land use, 2011

Table 6: Jalalpur: Land use, 2011

\begin{tabular}{|c|c|c|c|c|}
\hline \multirow{2}{*}{\begin{tabular}{|c} 
S. \\
No
\end{tabular}} & \multirow[t]{2}{*}{ Land Class } & \multicolumn{3}{|c|}{ Area in } \\
\hline & & Hectare & Sq. Km. & Per cent \\
\hline 1 & Settlement & 176.40 & 1.76 & 76.53 \\
\hline 2 & Agricultural Land & 3.023 & 0.04 & 1.32 \\
\hline 3 & Orchard/Tree & 0.43 & 0.004 & 0.19 \\
\hline 4 & Open/Vacant Land & 8.35 & 0.08 & 3.62 \\
\hline 5 & Water bodies & 0.97 & 0.01 & 0.42 \\
\hline 6 & Road & 41.30 & 0.41 & 17.92 \\
\hline 7 & Area not included in Nagar Palika. & - & 0.03 & - \\
\hline & Total & 230.49 & 2.30 & 100 \\
\hline
\end{tabular}

\section{Constraints Mapping}

After identifying the open land and its ownership the next step was to narrow down the area of search. Therefore constraints mapping was done. The constraint mapping is based on the locational criteria"s specified by the CPCB. Soils of the town is loamy to clayey loamy in texture with very high moisture retention and very low percolation rate. The average depth of

ground water is 40 feet with seasonal and locational variation. For, it falls below 45 feet during summers and about 38 feet during rainy seasons. Buffers of specified radius were drawn around the important land use categories. All the maps are overlaid with Land use to find out the suitable site for disposal.

\section{Identification of Land fill Site}

Being too small and densely populated, it was difficult to find out open space for dumping. For the identification of landfill site Pond/lake, river and road buffers were created (Figures 9, 10 and 11). Applying the procedure adopted earlier the over lay analysis reveals that land fill site can only be located in the extreme eastern part amidst the agricultural fields. The site is proposed to be located in Usmanpur Dakshini ward (ward no. 2). But this is private land and the local body will have to acquire it. Figure 12 shows the location of identified site. Only five hectare of land is sufficient for the site and at current rate it will be functional for the next eight years.

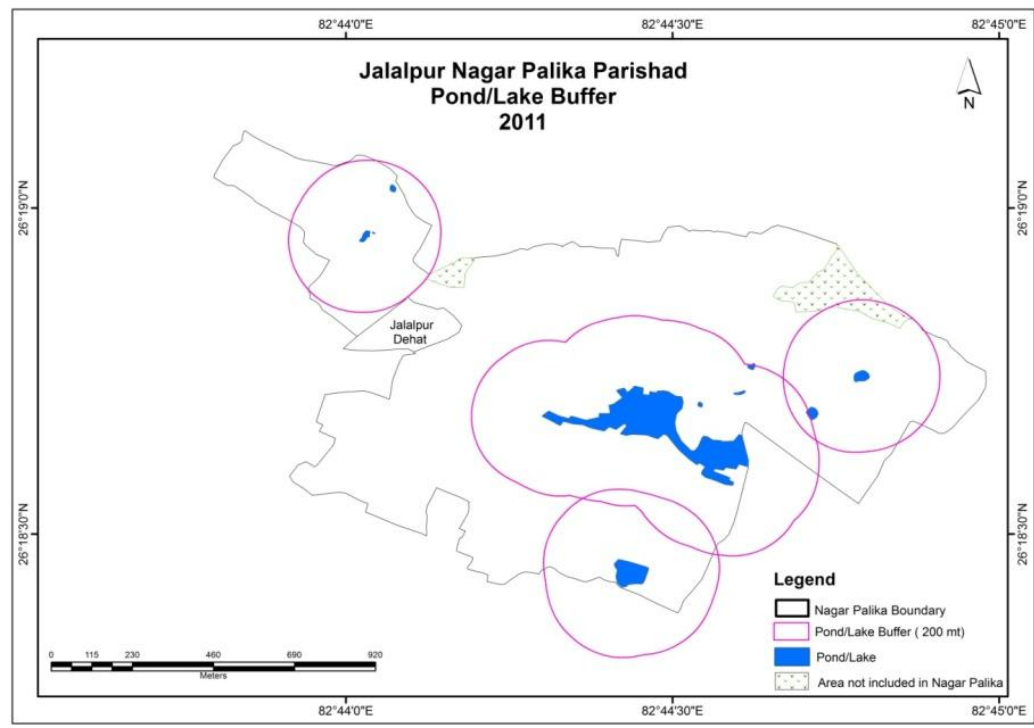

Figure 9: Jalalpur: Pond Buffer 


\section{International Journal of Science and Research (IJSR) \\ ISSN (Online): 2319-7064}

Index Copernicus Value (2013): 6.14 | Impact Factor (2014): 5.611

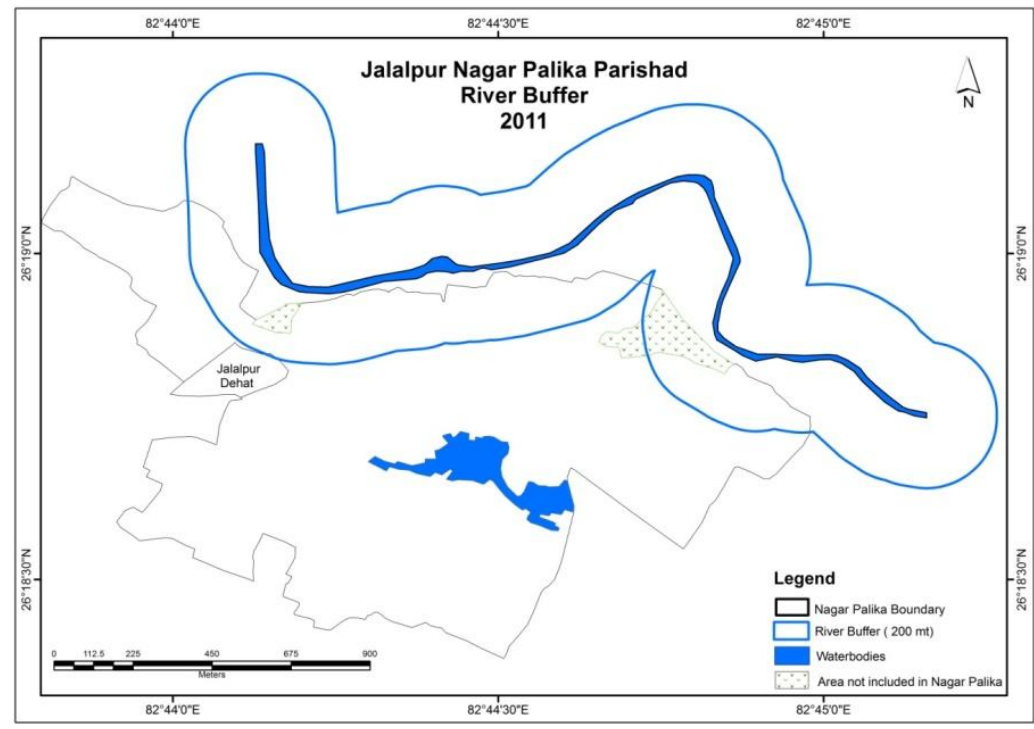

Figure 10: Jalalpur: River Buffer

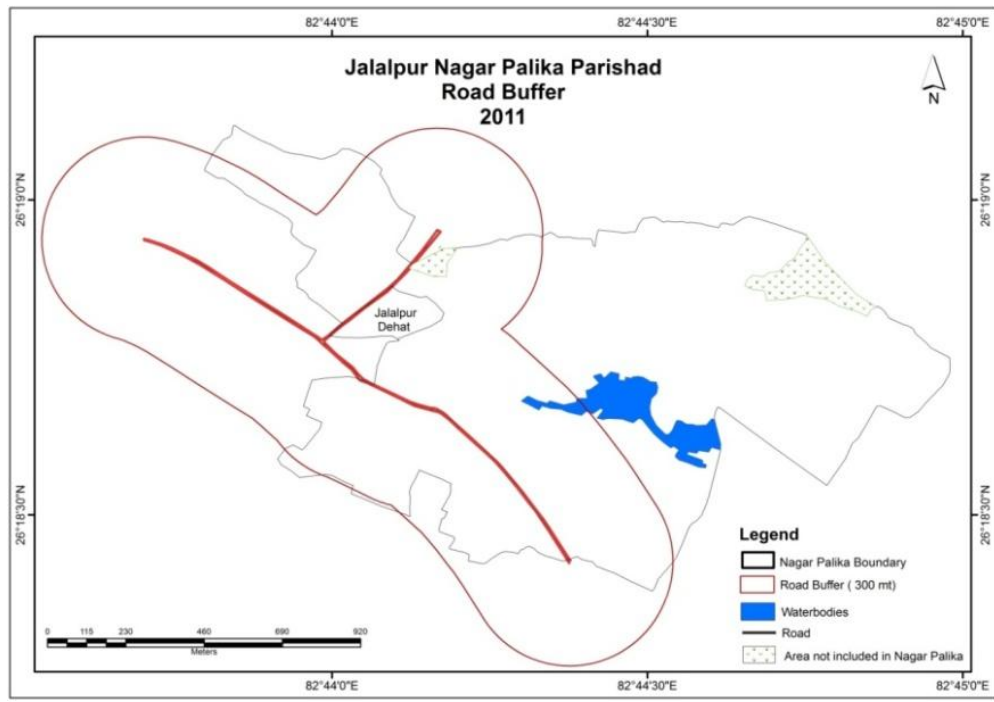

Figure 11: Jalalpur: Road Buffer

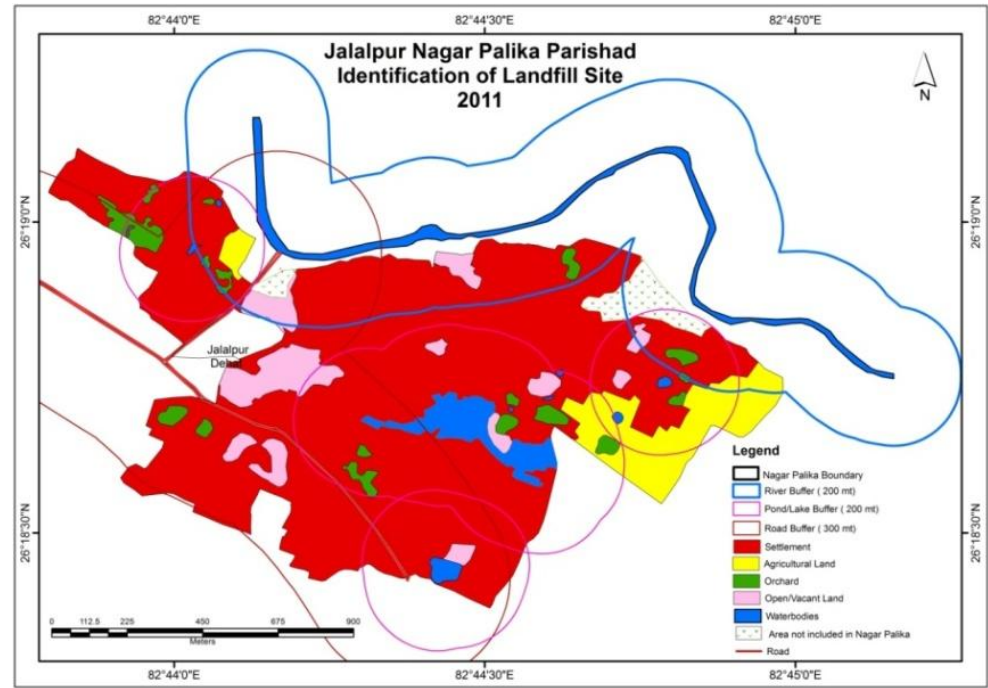

Figure 12: Location of Proposed Landfill Site

The proposed disposal site in Jalalpur is amidst the agricultural field and close to the settlement. The site has a score of 630.95. It means the site is highly sensitive and needs relocation but the problem is that there is no space for disposal. Both the environment and receptor related parameters (283.75 and 167.75) are too high. Though, it is highly sensitive yet will save the river from illegal dumping, encroachment and pollution. In such a situation the site with appropriate engineering measures may be used till the limits of the Nagar Palika are redefined and some other site is

Volume 5 Issue 2, February 2016 


\section{International Journal of Science and Research (IJSR) \\ ISSN (Online): 2319-7064 \\ Index Copernicus Value (2013): 6.14 | Impact Factor (2014): 5.611}

identified.

\section{Financial Management}

The Nagar Palika is very poor as of the total annual expenditure of 2,50,00,000/ only 23 lakh is the earning in the form of taxes rest is in the form of aid from the state government. Of the total expenditure about Rs. 13, 66, 6500/ is spent on waste management. The major expenditure (Rs. 1, 34, 70,000, (53.88 per cent) is on salaries of Safai
Karamchari. Beside about 18, 24, 000/ is spent on pension. Rest is spent on salaries of the office staff and maintenance. The per capita expenditure on waste management is about Rs. 417/. In the proposed plan the budget has been increased to 22048000 / (33.39 per cent) of which $18,44,1000 /$ (83 per cent) will be on waste management (Table 7). This way the per capita expenditure on waste management will be Rs. $635 /$.

Table 7: Jalalpur: Existing and Proposed Expenditure on Solid Waste, 2011

\begin{tabular}{|c|c|c|c|c|c|}
\hline \multirow[b]{2}{*}{ SN. } & \multirow[b]{2}{*}{ Budget Item/Trade Post } & \multicolumn{2}{|r|}{ Existing } & \multicolumn{2}{|c|}{ Proposed } \\
\hline & & Number & Annual Expenditure & Number & Annual Expenditure \\
\hline 1 & Sanitary Inspector(vaccinator) & - & - & - & - \\
\hline 2. & Jamadar (Safai Naik) & 5 & $9,90,000 /$ & 5 & $9,90,000 /$ \\
\hline 3 & Safai Karamchari- permanent & 80 & $1,24,80,000 /$ & 80 & $1,24,80,000 /$ \\
\hline \multirow[t]{2}{*}{4.} & Safai Karamchari -Contractual & - & - & 35 & $42,00,000 /$ \\
\hline & Total & 85 & $1,34,70,000 /$ & 120 & $1,76,70,000 /$ \\
\hline 1 & Drivers (contractual) & - & - & 2 & 86,400 \\
\hline 2 & Assistant Engineer civil & - & - & 1 & $2,16,000 /$ \\
\hline 3 & Assistant Engineer water works & - & - & - & - \\
\hline 4 & Executive engineer & - & - & - & - \\
\hline 5 & Clerks(babu) & 3 & $7,92,000 /$ & 3 & $7,92,000$ \\
\hline 6 & Watchman & - & - & - & - \\
\hline \multirow[t]{2}{*}{7} & Peon & 1 & $1,44,000 /$ & 1 & $1,44,000$ \\
\hline & Total & 4 & $9,36,000 /$ & 7 & $12,38,400 /$ \\
\hline 1 & Trolleys/showels/spades & & & & $75000 /$ \\
\hline \multirow[t]{2}{*}{2} & Tractor & - & & 1 & $3,50,000 /$ \\
\hline & Total & - & & 1 & $4,25,000 /$ \\
\hline \multirow[t]{2}{*}{1} & Staff Uniform & & $1,04,000$ & & $1,49,500 /$ \\
\hline & Total & & $1,04,000 /$ & & $1,49,500 /$ \\
\hline \multirow[t]{2}{*}{1} & Dustbin & 25 & 92,500 & 73 & $2,70,100 /$ \\
\hline & Total & 25 & 92,500 & 73 & $2,70,100 /$ \\
\hline 1 & Diesel(Waste Collection) & & & & $40,000 /$ \\
\hline \multirow[t]{2}{*}{2} & Diesel(water supply) & - & $42,000 /$ & & $55,000 /$ \\
\hline & Total & - & $42000 /$ & & $95,000 /$ \\
\hline \multirow[t]{2}{*}{1} & Maintenance and Repairs & - & 60,000 & & $75,000 /$ \\
\hline & Total & - & 60,000 & & $75,000 /$ \\
\hline \multirow[t]{3}{*}{1} & Pension & - & $18,24,000$ & & $22,00,000 /$ \\
\hline & Total & & $18,24,000$ & & $22,00,000 /$ \\
\hline & Grand Total & 114 & $1,65,28,500 /$ & 201 & $2,20,48,000 /$ \\
\hline
\end{tabular}

Table 8: Jalalpur: Waste Management at a Glance, 2011

\begin{tabular}{|c|l|c|c|c|}
\hline S.No. & \multicolumn{1}{|c|}{ Item } & Existing & Proposed & Change in per cent \\
\hline & Expenditure & $1,65,28,500 /$ & $2,20,48,000 /$ & 33 \\
\hline 1 & Daily waste collection & 2 ton & 4 ton & 100 \\
\hline & Annual Waste Collection(ton) & 730 ton & 1460 ton & 100 \\
\hline 2 & Waste collection efficiency & $29 \%$ & $57 \%$ & 96.55 \\
\hline 4 & Cost of Collection ( Rs/ ton) & 22641 & 15101 & -33.31 \\
\hline 5 & Collection Cost(Rs/ head) & 570 & 760 & 33.33 \\
\hline 6 & Dustbins & 25 & 73 & 192 \\
\hline 7 & Sweepers & 80 & 115 & 43.75 \\
\hline 8 & Sweeper-Population Ratio & 365.45 & 254.22 & -30.43 \\
\hline 9 & Sweeper-road length & $1: 618$ & $1: 429$ & -30.58 \\
\hline 10 & Bin-population ratio & 1181.44 & 400.49 & -66.10 \\
\hline
\end{tabular}

It emerges from the analysis is that this level of efficiency could be achieved largely because of modest increase in the Safai Karamchari and proper route planning. The cost of SWM arrived at is, though, not exhaustive but tries to reach the closest approximation of the final cost.

\section{Conclusions}

The volume and rate of generation is low in Jalalpur. The town generates about 7.83 ton daily with an average generation rate of $0.270 \mathrm{~kg}$. It is found that social, demographic and industrial structure of the city is directly related to the rate of generation and composition of solid 


\section{International Journal of Science and Research (IJSR) \\ ISSN (Online): 2319-7064 \\ Index Copernicus Value (2013): 6.14 | Impact Factor (2014): 5.611}

waste. Heap of garbage and littered streets are noticed all over the city space which indicates the pathetic attitude of the local bodies as well as the common man. The deployment of sanitary staff is skewed affecting the work force efficiency. There is no co-relation between manpower deployment and quantity of waste generation, population served or area of the circle. The result is that sweeper population ratio, sweeper-road length ratio and binpopulation ratio are far below the standard norms. The spacing of dustbins is also random and largely determined by the local influence. It is important to note that there is no segregation of waste neither at source nor at destination.

Till date no official site has been identified. Based on the constraints mapping a landfill site has been identified but it is highly sensitive to environmental and receptor parameters. The sensitivity can be brought down to moderate level by adopting engineering measures. It is estimated that the proposed site in Jalalpur will require an area of only five hectare and be functional for 8 years.

Generation of waste cannot be stopped rather it will tend to rise and therefore instead of considering it as havoc efforts should be made to reduce the waste quantity and to make the best use of it. The waste hierarchy, promoted by the United Nations Conference on Environment and Development and Habitat II which upholds the fundamental principle ,prevention is better than cure ${ }^{\text {ee }}$ is of course a better way of waste management but a closer look at the current scenario reveals that waste needs to be treated holistically. A landfill is only an end-of-pipe solution. By dumping the waste in a landfill, the problem is only deferred, not solved. Land disposal of waste should ideally be the last option when all other efforts or options of waste disposal and minimization like recycling and reuse, treatment processes are done.

\section{References}

[1] Agamuthu and Hansen, (2007): Universities in capacity building in sustainable development: focus on solid waste management and technology, Waste Management \& Research 25(3):241-6.

[2] Al-Khatib I., et. al., (2010): "Solid waste characterization, quantification and management practices in developing countries. A Case Study: Nabulus District - Palestine" Journal of Environmental Management, 91, 1131-1138.

[3] Central Pollution Control Board (CPCB, 2003): Guidelines for the selection of site for land filling. New Delhi: Central Pollution Control Board.

[4] Central Public Health and environmental Engineering Organization (CPHEEO, 2010): Technical EIA Guidance manual for common municipal solid waste management facilities, Ministry of Environment and Forest.

[5] Disha et. al., (2001): India country report. pp. 1-5. In: Proceedings of Waste Not Asia. Taipei, Taiwan. Electronic publication URL: www.swlf.ait.ac.th/data/Research\%20Reports/Municipa $1 \%$ 20Solid\%20Waste\%20Management\%20in\%20Asia.p

[6] Grossmann et. al., (1974): Waste generation models for Solid Waste Collection, Journal of Environmental
Engineering Division, 100.

[7] Kumar and Gaikwad (2004): Municipal solid waste management in Indian Urban Centres: An approach for betterment. In K. R. Gupta (Ed.), Urban development debates in the new millennium (pp. 100-111). New Delhi: Atlantic Publishers \& Distributor.

[8] Medina, M. (1997): The effect of income on municipal solid waste gene ration rates for countries of varying levels of economic development: A model, journal of Resource Management Technology, Vol. 24.

[9] Siddiqui, M. A. et al., (2012): "Solid Waste Management in Moradabad, India", Indian Journal of Remote Sensing, Springer, Indian Society of Remote Sensing, Dehradun.

[10] Singhal, S and Pandey, S. (2001): Solid waste management in India: status and future directions. TERI Information Monitor on Environmental Science, 6 (1).

[11] Visvanathan et al., 2004): Municipal Solid Waste Management in Asia: Asian Regional Research Program on Environmental Technology (ARRPET), Asian Institute of Technology publications.

[12] Wertz, K.L. (1976): "Economic Factors Influencing Households' Production of Refuse" Journal of Environmental Economics and Management 2: 263272. 